HELMINTHOLOGIA, 52, 3: 188 - 194, 2015

\title{
Epidemiological risks of endoparasitoses spread by municipal waste water
}

\author{
A. DUDLOVÁ1, P. JURIŠ ${ }^{1 *}$, P. JARČUŠKA ${ }^{1}$, L. ČISLÁKOVÁ1 I. PAPAJOVÁ2 ${ }^{2}$ V. KRČMÉRY3

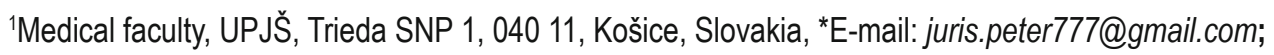 \\ ${ }^{2}$ Parasitological Institute SAS, Hlinkova 3, 040 01, Košice, SR; \\ ${ }^{3}$ St. Elizabeth University of Health and Social Sciences, 81000 Bratislava, SR
}

\section{Article info}

Received March 18, 2015 Accepted June 3, 2015

\begin{abstract}
Summary
The occurrence of developmental stages of endoparasite germs (cysts, oocysts, protozoa, and helminth eggs) as an indirect detection factor of endoparasitoses circulation in the environment, was examined in raw municipal wastewater, sludge and biologically cleaned waste water. Examination of municipal wastewater and sludge from five monitored wastewater treatment plants (WWTPs) in east Slovakia, from various fractions of municipal wastewater, confirmed $35.87 \%$ positivity of samples for the endoparasitic germs. Among of all analysed samples $11.09 \%$ were protozoan 00 (cysts) and $20.87 \%$ were helminth eggs. $3.91 \%$ of samples showed positivity to both the helminth eggs and protozoan 00 (cysts). In the raw wastewater the protozoa comprised of Giardia spp. (1.08\%) and Entamoeba spp. (1.08\%). The helminth eggs primarily consisted of Ascaris spp. (4.35\%) and strongyle-type eggs (3.26\%). No germs of protozoa or helminths were found in the treated wastewater. However, the highest presence of the germs was found in drained stabilised sludge. The average number of oo(cysts) $/ \mathrm{kg}$ was $2.86 \pm 0.24$ and the average number of helminth eggs $/ \mathrm{kg}$ was $5.77 \pm 0.09$. In all kinds of sludge, obtained during the process of wastewater treatment, there were protozoan (Giardia spp., Cryptosporidium spp., Entamoeba spp.) and helminths eggs (Ascaris spp., Trichuris spp., Taenia spp., Hymenolepis spp., or strongyle-type eggs) presented. In drained (condensed) stabilised sludge the eggs of Capillaria spp. and Toxocara spp. were also detected. From the epidemiological aspect the sewage sludge, due to high concentration of protozoal oo(cysts) or helminth eggs, represents a significant epidemiological risk for the endoparasitoses dissemination.
\end{abstract}

Keywords: oo(cysts) of protozoa; helminth eggs; municipal waste water; sewage sludge; epidemiology of endoparasitic germs

\section{Introduction}

Prevalence of endoparasitoses, due to an increase in the density of world population, has an increasing tendency not only in developing countries but due to the migration pressure also in developed countries including the EU. This in general represents a significant public-health problem. Intestinal infections induced by protozoa and helminths affect about 3.5 milliard people and they induce diseases in 450 million people worldwide where mostly children are affected (WHO, 2008). The most frequent incidence of parasitic diseases is in the poorest regions with low socio-econom- ical and living conditions, without hygienic and sanitary systems, and possibly without access to the clean drinking water. The environmental conditions are the determining factors in the transmission and dissemination of endoparasitoses in human population. Wastewater tends to be a source of pathogenic microorganisms including the endoparasitic germs. It represents a significant risk of the environmental contamination. Environmental conditions such as contamination of soil and water sources with municipal waste as well as the absence of wastewater treatment and subsequent utilization for fertilization and irrigation purposes contribute to the development and distribution of parasitic infections (Okojokwu et 
al., 2014). In Slovakia the incidence of endoparasitoses is especially linked with communities with low hygienic standards and without proper infrastructure. From the epidemiological point of view there are still some relatively risky communities. Those are villages and small urban settlements lacking sewerage and wastewater treatment systems (Rimárová, 2010; Juriš \& Papajová, 2012). The monitoring goal was to determine the current situation regarding the incidence of germs of endoparasites in municipal wastewater and sludge from WWTPs. The analysis was associated with subsequent assessment of the epidemiological risk for the public health.

\section{Material and Methods}

The samples of municipal wastewater and sludge were collected from five wastewater treatment plants (WWTPs) using the technology of mechanical-chemical-biological water purification. River Torysa was the water source for the examined WWTPs located in Torysa, Lipany, Sabinov and Prešov. For comparison, we also monitored the WWTP Sečovce in another region whose water source is the rivulet Trnávka. WWTPs differed in the number of corresponding inhabitants: 86,998 (WWTP Prešov), 32,400 (WWTP Prešov), 11,405 (WWTP Sečovce), 10,000 (WWTP Lipany), 8,500 (WWTP Torysa). The incidence of germs of endoparasites (the presence of oo(cysts) of protozoa, and helminth eggs) was examined in raw wastewater, biologically treated wastewater, raw sludge, activated sludge and drained stabilised sludge. Totally 184 samples of wastewater and 276 samples of sludge were examined. The sample tested consisted of $250 \mathrm{ml}$ of wastewater, raw and activated sludge or $250 \mathrm{~g}$ of drained stabilised sludge. For the detection the oo(cysts) aqueous $\mathrm{ZnSO}_{4}$ solution (Bartlett et al. 1978) and eggs method according Cherepanov (1982) were used. The method consisted of sedimentation, centrifugation with sacharose where the specific weight for saturated solution was 1.30 for both, the liquid and solid fractions. Subsequently, the flotation samples were examined under the microscope. The biochemical analysis of raw and treated municipal wastewater was carried out in accordance to the valid Slovak technical standards and parameters of wastewater contamination listed under the Government regulation No. 269/2010 and in accordance with the Regulation of European Parliament and European Council (EC) No. 1137/2008 on the municipal wastewater treatment. For the statistical processing of the results the Chi square test- $X^{2}$ test (significance level $a=0.05$ ) the SPSS version 20 of statistical program was employed.

Table 1. Positive samples of municipal wastewater and sludge to the germs of endoparasites (\%)

\begin{tabular}{lcc}
\hline Germs of endoparasites & N/460 & $\mathbf{P}(\%)$ \\
\hline Protozoa / helminth eggs & 18 & 3.91 \\
Protozoan oo(cysts) & 51 & 11.09 \\
Helminth eggs & 96 & 20.87 \\
$\Sigma$ posit. samples & 165 & 35.87 \\
Negative samples & 295 & 64.13 \\
\hline N- number of examined samples, P- positivity &
\end{tabular}

\section{Results}

Analysis of 460 wastewater and sludge samples from WWTP revealed $35.87 \%$ positivity to the germs of endoparasites. The oo(cysts) of protozoa were recorded in $11.09 \%$ of samples, and helminth eggs were present in $20.87 \%$. In $3.91 \%$ of samples there was positivity to both the helminth eggs and protozoan oo(cysts) (Table 1).

Out of the total 92 raw wastewater samples examined 2 were found positive $(2.17 \%)$ for the presence of protozoan 00 (cysts); genus representation Giardia spp. (1.08 \%) and Entamoeba spp.

Table 2. Species representation of the germs of endoparasites in municipal wastewater and sludge from the WWTPS

\begin{tabular}{lccccc}
\hline $\begin{array}{l}\text { Generic or species } \\
\text { representation of } \\
\text { endoparasites }\end{array}$ & $\begin{array}{c}\text { RW } \\
\text { inflow } \\
(\mathbf{N = 9 2 )}\end{array}$ & $\begin{array}{c}\text { TW } \\
\text { outflow } \\
(\mathbf{N}=92)\end{array}$ & $\begin{array}{c}\text { Raw sludge } \\
(\mathbf{N}=88)\end{array}$ & $\begin{array}{c}\text { Activated } \\
\text { sludge } \\
(\mathbf{N}=88)\end{array}$ & $\begin{array}{c}\text { Drained stabilised } \\
\text { sludge } \\
(\mathbf{N}=100)\end{array}$ \\
\cline { 2 - 6 } & \multicolumn{5}{c}{ n posit./P \% } \\
\hline Giardia spp. & $1 / 1.08$ & 0 & $11 / 12.50$ & $7 / 7.95$ & $4 / 4.00$ \\
Cryprosporidium spp. & 0 & 0 & $1 / 1.14$ & $2 / 2.27$ & $3 / 3.00$ \\
Entamoeba spp. & $1 / 1.08$ & 0 & $2 / 2.27$ & $1 / 1.14$ & $1 / 1.00$ \\
Isospora spp. & 0 & 0 & 0 & 0 & $7 / 7.00$ \\
Ascaris spp. & $4 / 4.35$ & 0 & $17 / 19.32$ & $11 / 12.50$ & $48 / 48.00$ \\
Strongyle-type eggs & $3 / 3.26$ & 0 & $11 / 12.50$ & $6 / 6.82$ & $27 / 27.00$ \\
Trichuris spp. & 0 & 0 & $2 / 2.27$ & $2 / 2.27$ & $9 / 9.00$ \\
Capillaria spp. & 0 & 0 & 0 & 0 & $4 / 4.00$ \\
Toxocara spp. & 0 & 0 & 0 & 0 & $2 / 2.00$ \\
Taenia spp. & 0 & 0 & $9 / 10.23$ & $2 / 2.27$ & $9 / 9.00$ \\
Hymenolepis spp. & 0 & 0 & $2 / 2.27$ & $1 / 1.14$ & $2 / 2.00$ \\
\hline
\end{tabular}

RW- raw wastewater, TW- treated wastewater, $\mathrm{N}$ - number of examined samples, $\mathrm{n}$ posit. - number of positive, $\mathrm{P}$ - positivity 
Table 3. Germs of endoparasites in the raw wastewater from the WWTPs

\begin{tabular}{|c|c|c|c|c|c|c|c|c|c|}
\hline \multirow[b]{2}{*}{ WWTP } & \multirow[b]{2}{*}{$\begin{array}{l}\text { Number of } \\
\text { samples (N) }\end{array}$} & \multicolumn{4}{|c|}{ Oo(cysts) of protozoa } & \multicolumn{4}{|c|}{ Helminth eggs } \\
\hline & & $\mathrm{n}(\%)$ & $\begin{array}{l}\text { Number of } \\
\text { oo(cysts)/l }\end{array}$ & $\begin{array}{c}\bar{X} \pm \mathrm{SD} \\
\text { oo(cysts)/l }\end{array}$ & $\begin{array}{c}X^{2} \\
(p) \\
\text { RW/TW }\end{array}$ & n (\%) & $\begin{array}{l}\text { Number } \\
\text { of eggs/l }\end{array}$ & $\begin{array}{c}\bar{X} \pm \mathrm{SD} \text { of } \\
\text { eggs /I }\end{array}$ & $\begin{array}{c}X^{2} \\
\text { (p) } \\
\text { RW/TW }\end{array}$ \\
\hline WWTP Torysa & 12 & 0 & 0 & 0 & - & 0 & 0 & 0 & - \\
\hline WWTP Lipany & 20 & 0 & 0 & 0 & - & $3(15.00)$ & 8 & $2.13 \pm 0.71$ & $0.0488^{*}$ \\
\hline WWTP Sabinov & 24 & $2(8.33)$ & 0.83 & $1.66 \pm 0.83$ & 0.1861 & $3(12.50)$ & 4 & $0.88 \pm 0.29$ & 0.1022 \\
\hline WWTP Prešov & 20 & 0 & 0 & 0 & - & $1(5.00)$ & 5 & $0.20 \pm 0.20$ & 0.3619 \\
\hline WWTP Sečovce & 16 & & 0 & 0 & - & 0 & 0 & 0 & - \\
\hline$\Sigma$ & 92 & $2(2.17)$ & 0.16 & $0.33 \pm 0.08$ & & $7(7.61)$ & 3.4 & $0.62 \pm 0.08$ & \\
\hline
\end{tabular}

WWTP- wastewater treatment plant, $\mathrm{N}$ - number of examined samples, $\mathrm{n}$ - number of positive samples, $\bar{X} \pm \mathrm{SD}$ - the average number and standard deviation, $\mathrm{X}^{2}$ test, $p$ value expressing statistically significant difference in the presence of germs (endoparasites) between raw wastewater (RW) and treated wastewater (TW) Significance level: * $p \leq 0.05,{ }^{* *} p \leq 0.01,{ }^{* * *} p \leq 0.001$

$(1.08 \%)$. The mean number of oo(cysts) per liter $(\bar{x} \pm \mathrm{SD} / \mathrm{l})$ was $0.33 \pm 0.08$. Seven raw wastewater samples were positive for the presence of helminth eggs $(7.61 \%)$ where the species Ascaris spp. (4.35\%) and strongyle-type eggs (3.26\%) were detected. The mean number of helminth eggs per a liter of raw wastewater $(\bar{x} \pm \mathrm{SD} / \mathrm{l})$ was $0.62 \pm 0.08$. All 92 samples collected from treated wastewater were tested negative for the presence of endoparasitic germs. In WWTP Lipany the statistically significant difference $\left(X^{2}\right.$, $p \leq 0.05$ ) in the incidence of the helminth eggs was found (Table 2 and 3$)$.

Out of 88 raw sludge samples the presence of protozoal oo(cysts) was confirmed in 12 of them (13.63\%). The species of Giardia spp. (12.50\%), Entamoeba spp. (2.27\%), and Cryptosporidium spp. (1.14 \%) were confirmed. The mean number of oo(cysts) per liter $(\bar{x} \pm \mathrm{SD} / \mathrm{l})$ was $1.64 \pm 0.14$. The eggs of Ascaris spp. (19.32\%), strongyle-type eggs (12.50\%), Trichuris spp. (2.27\%), Taenia spp. (10.23\%) and Hymenolepis spp. $(2.27 \%)$ were present in 32 samples of raw sludge $(36.36 \%)$. The mean number of helminth eggs per liter $(\bar{x} \pm \mathrm{SD} / \mathrm{l})$ in raw sludge was $3.05 \pm 0.09$. The statistically significant difference $(p \leq 0.05)$ in the presence of the endoparasitic germs was found between raw wastewater and raw sludge. The occurrence of protozoa was significantly higher in raw sludge of WWTP Lipany and WWTP Prešov. The presence of helminths eggs was significantly higher in raw sludge WWTP Prešov and WWTP Sečovce (Tab. 2 and Tab. 4).

Out of the total 88 samples from activated sludge eight samples were positive for the presence of protozoan oo(cysts) $(9.09 \%)$. Generically Giardia spp. (7.95 \%), Cryptosporidium spp. (2.27 \%), and Entamoeba spp. (1.14\%) were identified. The mean number of oo(cysts) per a liter ( $\bar{x} \pm \mathrm{SD} / \mathrm{l})$ was $1.88 \pm 0.24$. The number of positive samples for the presence of protozoa was the lowest of all kinds of sludge. Helminth eggs were present in 16 samples $(18.18 \%)$ and the mean number of helminth eggs per liter $(\bar{x} \pm \mathrm{SD} / \mathrm{l})$ in activated sludge was $2.008 \pm 0.13$, what also represents the lowest value. According to the generic or species representation following egg types were detected: Ascaris spp. (12.50\%), strongyle-type eggs (6.82\%), Trichuris spp. (2.27\%), Taenia spp. (2.27\%), Hymenolepis spp. (1.14\%). Based upon the $X^{2}$ test analysis the statistically significant difference in the presence of protozoa in WWTP Sečovce between raw wastewater and activated sludge was confirmed. There was significantly higher number of positive samples in activated sludge. The presence of helminth eggs was also significantly higher in activated sludge from WWTP Torysa and Sečovce (Table 2 and Table 5).

Out of the total 100 examined samples of drained stabilised sludge 12 samples were positive for the presence of protozoa

Table 4. Germs of endoparasites in raw sludge from the WWTPs

\begin{tabular}{|c|c|c|c|c|c|c|c|c|c|}
\hline \multirow[b]{2}{*}{ WWTP } & \multirow[b]{2}{*}{$\begin{array}{l}\text { Number of } \\
\text { samples (N) }\end{array}$} & \multicolumn{4}{|c|}{ Oo(cysts) of protozoa } & \multicolumn{4}{|c|}{ Helminth eggs } \\
\hline & & $\mathrm{N}(\%)$ & $\begin{array}{l}\text { Number of } \\
\text { oo(cysts)/l }\end{array}$ & $\begin{array}{c}\bar{X} \pm \mathrm{SD} \\
\text { oo(cysts)/l }\end{array}$ & $\begin{array}{c}X^{2} \\
(p) \\
\text { RW/TW }\end{array}$ & n (\%) & $\begin{array}{l}\text { Number } \\
\text { of eggs/l }\end{array}$ & $\begin{array}{l}\bar{X} \pm \mathrm{SD} \\
\text { eggs /I }\end{array}$ & $\begin{array}{c}X^{2} \\
(p) \\
\text { RW/TW }\end{array}$ \\
\hline WWTP Torysa & 12 & 0 & 0 & 0 & - & $1(8,33)$ & 0.25 & $0.33 \pm 0.33$ & 0.3070 \\
\hline WWTP Lipany & 16 & $3(18.75)$ & 1.75 & $2.33 \pm 0.77$ & $0.0429^{*}$ & $6(37.50)$ & 7.75 & $5.16 \pm 0.86$ & 0.1213 \\
\hline WWTP Sabinov & 20 & $2(10.00)$ & 1.8 & $3.60 \pm 1.80$ & 0.8497 & $7(35.00)$ & 8.0 & $3.66 \pm 0.52$ & 0.0767 \\
\hline WWTP Prešov & 24 & $7(29.16)$ & 4.0 & $2.28 \pm 0.33$ & $0.0085^{\star *}$ & $8(33.33)$ & 6.0 & $2.00 \pm 0.25$ & $0.0204^{*}$ \\
\hline WWTP Sečovce & 16 & 0 & 0 & 0 & - & $10(62.50)$ & 10.25 & $4.10 \pm 0.41$ & $0.0045^{* *}$ \\
\hline$\Sigma$ & 88 & $12(13,63)$ & 1.51 & $1.64 \pm 0.14$ & & $32(36.36)$ & 6.45 & $3.05 \pm 0.09$ & \\
\hline
\end{tabular}

Symbols used - see legend in Table 3 
Table 5. Germs of endoparasites in activated sludge from the WWTPs

\begin{tabular}{|c|c|c|c|c|c|c|c|c|c|}
\hline \multirow[b]{2}{*}{ WWTP } & \multirow[b]{2}{*}{$\begin{array}{l}\text { Number of } \\
\text { samples }(\mathrm{N})\end{array}$} & \multicolumn{4}{|c|}{ Oo(cysts) of protozoa } & \multicolumn{4}{|c|}{ Helminth eggs } \\
\hline & & $\mathrm{n}(\%)$ & $\begin{array}{l}\text { Number of } \\
\text { oo(cysts)/l }\end{array}$ & $\begin{array}{c}\bar{X} \pm \mathrm{SD} \\
\text { oo(cysts)/l }\end{array}$ & $\begin{array}{c}X^{2} \\
(p) \\
\text { RW/TW }\end{array}$ & $\mathrm{n}(\%)$ & $\begin{array}{l}\text { Number of } \\
\text { eggs/l }\end{array}$ & $\begin{array}{c}\bar{X} \pm \text { SD of } \\
\text { eggs /I }\end{array}$ & $\begin{array}{c}X^{2} \\
(p) \\
\text { RW/TW }\end{array}$ \\
\hline WWTP Torysa & 16 & $1(6.25)$ & 0.75 & $0.75 \pm 0.75$ & 0.3764 & $6(37.50)$ & 2.5 & $1.66 \pm 0.28$ & $0.0168^{* *}$ \\
\hline WWTP Lipany & 16 & $2(12.50)$ & 1.75 & $3.50 \pm 1.75$ & 0.1014 & $2(12.50)$ & 1.0 & $2.00 \pm 1.00$ & 0.8274 \\
\hline WWTP Sabinov & 24 & $1(4.16)$ & 0.67 & $0.66 \pm 0.66$ & 0.5509 & $2(8.33)$ & 0.67 & $1.33 \pm 0.67$ & 0.6366 \\
\hline WWTP Prešov & 16 & 0 & 0 & 0 & - & $1(6.25)$ & 0.5 & $0.25 \pm 0.25$ & 0.8652 \\
\hline WWTP Sečovce & 16 & $4(25.00)$ & 3.75 & $4.50 \pm 1.13$ & $\underset{* * *}{0.0001}$ & $5(31.25)$ & 6.0 & $4.80 \pm 0.96$ & $0.0360^{*}$ \\
\hline$\Sigma$ & 88 & $8(9.09)$ & 1.38 & $1.88 \pm 0.24$ & & $16(18.18)$ & 2.13 & $2.008 \pm 0.13$ & \\
\hline
\end{tabular}

Symbols used - see legend in Table 3

(12.00\%). Similarly to in raw or activated sludge there were Giardia spp. (4.00\%), Cryptosporidium spp. (3.00\%), Entamoeba spp. (1.00\%), and Isospora spp. (7.00\%) 00(cysts) present.

The mean number of oo(cysts) per a kilogram $(\bar{x} \pm \mathrm{SD} / \mathrm{kg}$ ) was $2.86 \pm 0.24$. This was the highest quantity when compared with the other kinds of sludge. In comparison to the other types of sludge the presence of helminth eggs in drained stabilised sludge was at the highest level $(58.00 \%)$. The mean number of eggs per a kilogram ( $\bar{x} \pm \mathrm{SD} / \mathrm{kg})$ was also the highest $(5.77 \pm 0.09)$ as well. The predominant eggs were Ascaris spp. (48.00\%) and strongyle-type eggs $(27.00 \%)$. Out of the other helminth eggs detected there were Trichuris spp. (9.00\%), Capillaria spp. (4.00\%), Toxocara spp. (2.00\%), from cestodes Taenia spp. (9.00\%), and Hymenolepis spp. (2.00\%). The quadrate Chí test confirmed the statistical difference between raw wastewater and drained stabilised sludge in all examined WWTPs. The presence of helminths was significantly higher in drained stabilised sludge from WWTP Torysa, WWTP Lipany, WWTP Sabinov, WWTP Prešov and WWTP Sečovce (Table 2 and Table 6).

Biochemical burden was observed in the raw and treated wastewater of monitoring municipal wastewater treatment plants. The list of the selected biochemical indicators is summarized in Tab.7.
Biochemical parameters determined in laboratory examination corresponded with standards limit values. The process of purification of waste water was carried out in optimal mode. Tab. 7 shows the average values of biochemical markers during the entire monitored period.

\section{Discussion}

The municipal wastewater before treatment contains a large amount of pathogenic microorganisms. Out of them the agents of endoparasitic infections represent a serious risk threat to the public health (Mahvi \& Kia, 2006). A lot of studies refer on the presence of endoparasites in raw wastewater. Most common are protozoa such as Giardia spp., Cryptosporidium spp., Entamoeba histolytica (Khouja et al., 2010), Cyclospora cayetanensis, (Galván et al., 2013), Isospora spp., Toxoplasma gondii (Demar et al., 2007) and helminths corresponding to Ascaris lumbricoides, Trichostrongylus spp., Enterobius vermicularis, Ancylostoma duodenale, Necator americanus, Taenia spp., Hymenolepis nana (Mahvi \& Kia, 2006; Ben Ayed et al., 2009; Okojokwu et al., 2014, Schaechter, 2009). In wastewater monitored for the presence of the endoparasitic germs we have found hygienically significant contamination. Thus

Table 6. Germs of endoparasites in drained stabilised sludge from the WWTPs

\begin{tabular}{|c|c|c|c|c|c|c|c|c|c|}
\hline \multirow[b]{2}{*}{ WWTP } & \multirow[b]{2}{*}{$\begin{array}{l}\text { Number of } \\
\text { samples (N) }\end{array}$} & \multicolumn{4}{|c|}{ Oo(cysts) of protozoa } & \multicolumn{4}{|c|}{ Helminth eggs } \\
\hline & & $\mathrm{n}(\%)$ & $\begin{array}{c}\text { Number } \\
\text { oo(cysts)/kg }\end{array}$ & $\begin{array}{c}\bar{X} \pm \mathrm{SD} \\
\text { oo(cysts)/kg }\end{array}$ & $\begin{array}{c}X^{2} \\
(p) \\
\text { RW/TW }\end{array}$ & $\mathrm{n}(\%)$ & $\begin{array}{c}\text { Number of } \\
\text { eggs } \\
/ \mathrm{kg}\end{array}$ & $\begin{array}{l}\bar{X} \pm \text { SD } \\
\text { eggs /kg }\end{array}$ & $\begin{array}{c}X^{2} \\
(p) \\
\text { RW/TW }\end{array}$ \\
\hline WWTP Torysa & 16 & $4(16.66)$ & 4.00 & $4.00 \pm 1.00$ & 0.0618 & $9(56.25)$ & 8.50 & $3.77 \pm 0.42$ & $0.0016^{* * *}$ \\
\hline WWTP Lipany & 24 & 0 & 0 & 0 & - & $13(54.16)$ & 31.83 & $9.79 \pm 0.75$ & $0.0071^{* *}$ \\
\hline WWTP Sabinov & 24 & $3(12.50)$ & 1.50 & $2.00 \pm 0.66$ & 0.6366 & $17(70.83)$ & 24.50 & $5.17 \pm 0.30$ & $0.0001^{* * *}$ \\
\hline WWTP Prešov & 20 & $5(25.00)$ & 10.40 & $8.32 \pm 1.66$ & $\underset{* *}{0.0168}$ & $13(65.00)$ & 17.80 & $5.48 \pm 0.42$ & $0.0001^{* * *}$ \\
\hline WWTP Sečovce & 16 & 0 & 0 & 0 & - & $6(37.50)$ & 6.50 & $4.66 \pm 0.78$ & $0.0226^{*}$ \\
\hline$\Sigma$ & 100 & $12(12.00)$ & 3.18 & $2.86 \pm 0.24$ & & $58(58.00)$ & 17.83 & $5.77 \pm 0.09$ & \\
\hline
\end{tabular}

Symbols used - see legend in Table 3 
Table 7. Biochemical parameters of municipal waste water contamination before and after the technological treatment in the WWTPs

\begin{tabular}{|c|c|c|c|c|c|c|}
\hline & & WWTP Torysa & WWTP Lipany & WWTP Sabinov & WWTP Prešov & WWTP Sečovce \\
\hline \multirow{2}{*}{$\mathrm{pH}$} & RW & 7.5 & 7.6 & 7.8 & 7.7 & 7.6 \\
\hline & TW & 7.3 & 7.8 & 7.6 & 7.7 & 7.6 \\
\hline \multirow{2}{*}{$\operatorname{COD}(\mathrm{mg} / \mathrm{l})$} & RW & 777.2 & 443.3 & 883 & 787.2 & 289 \\
\hline & TW & 20.7 & 24.3 & 26.6 & 30.8 & 24 \\
\hline \multirow{2}{*}{ BOD (mg/l) } & RW & 359.8 & 274.1 & 567.2 & 360.3 & 114 \\
\hline & TW & 2.1 & 2.3 & 2.2 & 3.4 & 7.5 \\
\hline \multirow{2}{*}{ SS (mg/l) } & RW & 613.8 & 259.2 & 343.8 & 456.8 & 99.1 \\
\hline & TW & 5.2 & 8.6 & 5 & 6.3 & 5.4 \\
\hline \multirow{2}{*}{ N-NO3- (mg/l) } & RW & 0.3 & 0.3 & 0.4 & 0.3 & 1.1 \\
\hline & TW & $5.6^{*}$ & $6.4^{*}$ & $6.6^{*}$ & $3.9^{*}$ & $20.8^{*}$ \\
\hline \multirow{2}{*}{$\mathrm{N}-\mathrm{NH} 4^{+}(\mathrm{mg} / \mathrm{l})$} & RW & 34.2 & 37 & 44.3 & 46.5 & 29.4 \\
\hline & TW & 1.9 & 0.9 & 0.3 & 1.9 & 0.1 \\
\hline \multirow{2}{*}{$\mathrm{P}-\mathrm{PO}^{3-}$ (mg/l) } & RW & 9 & 3.4 & 7.6 & 6.2 & 3.5 \\
\hline & TW & 0.5 & 2.7 & 0.3 & 0.2 & 2.6 \\
\hline
\end{tabular}

WWTP- wastewater treatment plant, RW- raw wastewater, TW-treated wastewater, COD- chemical oxygen demand, BOD- biological oxygen demand,

SS- suspended solids

Limit values for treated municipal waste water were assessed according to the Government regulation No. 269/2010 and in accordance with the

Regulation of European Parliament and Council (EC) No. 1137/2008 on The municipal wastewater treatment.

*values exceeding the limit concentrations in treated waste water

this type of water is unsuitable for direct fertilization or disposal because represents a serious epidemiological risk for the environment. In particular, ground water, sources of drinking water and soil are endangered. For that reason it is necessary to treat contaminated water in the wastewater treatment plants.

A lot of studies have confirmed that treatment does not necessarily remove all the germs of parasites and some of them remain present and are viable. The size of protozoan cysts Giardia spp. (8 $12 \mu \mathrm{m})$, Entamoeba histolytica $(9-14.5 \mu \mathrm{m})$ and oocysts Cryptosporidium spp. $(4.5-5.5 \mu \mathrm{m})$, Microsporidium spp. (1.8 $-5.0 \mu \mathrm{m})$ permits to persevere throughout the technological processes of wastewater treatment. Similarly to raw untreated wastewater the treated one may pose the same though reduced risk for water and the environment (Slifko et al., 2000). For example, Khanum et al. (2012) observed the presence of protozoa in municipal wastewater from wastewater treatment plants and confirmed their survival ability during treatment processes. Analysis of treated wastewater validated the presence of protozoa such as Giardia spp., Entamoeba spp., Entamoeba coli, Endolimax nana, Idoamoeba butschlii, and Balantidium coli. When samples were collected at the different steps of water treatment the amount of protozoa decreased towards the discharge phase of treatment. However, treatment did not result in complete protozoan removal. Khouja et al. (2010) also reported the presence of protozoa Cryptosporidium spp., Giardia spp., and Entamoeba spp. in treated wastewater. In addition, Seviour and Nielsen (2010) pointed out that $20 \%$ of Giardia spp. cysts and $33-100 \%$ of Cryptosporidium spp. oocysts remained in treated wastewater viable or infectious.

Some observations proved the presence of helminth eggs in treated water from the municipal wastewater treatment plants as well. There is constant presence of eggs such as Ascaris spp., Enterobius spp., Hymenolepis spp., and Strongyloides spp. (Cutolo et al., 2006). However, in our study the presence of the germs of endoparasites in treated water from mechanical-chemical-biological wastewater treatment plants was not confirmed. Therefore it seems that the treatment effectiveness in the municipal wastewater treatment plants examined was from the parasitological aspect fully effective. During the process of wastewater treatment, after the phase of sedimentation, the protozoal (0o)cysts and helminth eggs are accumulated in the sludge (Jiménez et al., 2010). Consequently, in the wastewater treatment plants an increased presence of protozoan cysts (Giardia spp., Entamoeba spp., and oocysts Cryptosporidium spp.) in raw sludge is identified. Cheng et al. (2009) reported that all the sludge samples analysed from the municipal wastewater treatment plants were positive for the presence of C. parvum, C. hominis oocysts and Giardia intestinalis cysts. Maximum oocysts concentration was detected in the primary raw sludge and therefore subsequent sanitation is recommended. The oocysts Cryptosporidium spp. can remain viable in the environment for more than a year. Therefore protozoan species are most spread in the environment and they can get clearly propagated through their germs. 
Guzmán et al. (2007) described that the presence of helminth eggs (Hymenolepis spp, Trichuris spp., Ascaris spp.) in raw sludge was at a low concentration while the incidence of Capillaria spp. was most frequent. Turovskiy and Mathai (2006) reported a high occurrence of helminth eggs including trematodes, nematodes and cestodes. The helminth concentration also depends on the epidemiological situation for the given territory and hygienic level as well. In our study Ascaris spp., strongyle-type eggs, Trichuris spp., Taenia spp., and Hymenolepis spp. were regularly found in a raw sludge.

Study of Mara and Horan (2003) identified the presence of protozoa (Giardia spp., Entamoeba spp., and Cryptosporidium spp., spores of microsporidia) and eggs of Taenia saginata, Ascaris spp., Trichuris spp., Hymenolepis spp. in the activated sludge. The concentration of endoparasites in activated sludge is usually low (less than 5 cysts/eggs per a litre). The samples from activated sludge exhibited the lowest concentrations of endoparasitic germs in all kinds of the sludge examined.

Konate et al. (2010) published the study, which was focused on the survival of protozoa and helminths in sewage sludge after the process of its stabilisation. Followed by the anaerobic stabilisation the presence of protozoa Entamoeba coli, Entamoeba histolytica, Giardia spp., and helminths Ascaris lumbricoides, Ancylostoma spp. was confirmed. In the analysed stabilised sludge a wide scale of germs of endoparasites (protozoa, nematodes, cestodes) were also identified. Generally the process of wastewater stabilisation eliminates about 70 - $99 \%$ of the protozoan 0o(cysts) and helminth eggs what is represented by the highest amount found in stabilised sludge (Jimenez, 2007). Our results have confirmed this fact. The highest contamination with the endoparasitic germs was recorded in stabilised sludge in $58 \%$ of positive samples.

Sedimentation is an effective technological phase that eliminates especially heavier helminth eggs and to a lesser degree protozoan cysts. Turovskiy and Mathai (2006) focused on the quantification of helminth eggs in municipal wastewater and sludge. Their results pointed out that the number of helminth eggs per kilogram reached in raw and activated sludge several hundreds and in drained stabilised sludge can be extended to several thousands.

The World Health Organisation recommends the concentration $\leq 1$ helminth egg/liter in wastewater used for irrigation and less than 1 helminth egg/g of sludge. The most important helminthic species are Ascaris lumbricoides, Trichuris trichiura, Ancylostoma duodenale and Necator americanus. The amount of intestinal helminth eggs in municipal wastewater in developing countries can be within the concentration range of 10 to more than 100,000 eggs per a liter of wastewater. In Europe it is $0-1$ egg per a liter of wastewater (WHO, 2006). The sludge samples analysed showed higher values of the mean number of oo(cysts) and eggs. This is associated with high risk of the environmental contamination and greater threat to the public health. Therefore hygienisation/disinfection of sludge as well as proper handling, disposal of sludge, or further safe use is suggested.

A significant fact is that the germs of parasites (eggs, cysts, o0cysts, sporocysts, larvae) are characterised by high tenacity in the environment due to the notably stemming from the construction of germ walls and their biological and physiological properties.
Among of protozoa the oocysts of the genera Cryptosporidium, Toxoplasma and the helminths thick-walled eggs of Ascaris, Toxocara, Fasciola, Taenia, Echinococcus spp. are the most resistant. Under favorable conditions of the external environment germs are able to survive from several months up to the years (Juriš et al., 1991, Dubinský et al., 2000).

\section{Conclusion}

We found that among of the many risks that can endanger public health is potential spreading of wide spectrum of endoparasitoses (Giardia spp., Cryptosporidium spp., Entamoeba spp., Isospora spp., Ascaris spp., strongyle-type eggs, Trichuris spp., Capillaria spp., Toxocara spp., Taenia spp., and Hymenolepis spp.) throughout the processing and handling of municipal wastewater. In comparison with inflowing wastewater to the WWTPs the presence of the developmental stages of protozoa and helminths was significantly higher in both the raw and activated sludge. The presence of helminth eggs (Ascaris spp., strongyle-type eggs, Trichuris spp., Capillaria spp., Toxocara spp., Taenia spp., and Hymenolepis spp.) was highly significant in drained stabilised sludge. Therefore the degree of contamination in drained stabilised sludge with the developmental stages of endoparasites (oocysts, helminth eggs) is epidemiologically extremely important. Municipal wastewater treatment plants within the technological process of treatment do not devitalize the developmental stages of endoparasites but concentrate them into various sludge fractions. In conclusion, the sludge fractions represent potential reservoirs for the endoparasitic diseases and epidemiologically should be considered very hazardous. Incorrect manipulation or ineffective sludge sanitation can cause epidemiologically significant contamination of the environment.

\section{Acknowledgement}

This study was supported and co-financed from the grant projects VEGA 2/0140/13.

\section{References}

Bartlett, M.S., Harper, K., Smith, N., Verbanac, P., Smit, J.W. (1978): Comparative evaluation of a modified Zinc Sulfate flotation technique. J. Clin. Microbiol., 7(6): $524-528$

Ben Ayed, L., SchiJven, J., Alouini, Z., Jemli, M., Sabbahi, S. (2009): Presence of parasitic protozoa and helminth in sewage and efficiency of sewage treatment in Tunisia. Parasitol. Res., 105(2): 393 - 406. DOI: 10.1007/s00436-009-1396-y

Cherepanov, A.A. (1982): Methods of laboratory centrals of cleaning plants on farms. Moscow, Publ. House Kolos, 64 pp.

Cheng, H. - W. A., Lucy, F.E., Graczyk, T.K., Broaders, M.A., TamaNG, L., Connolly, M. (2009): Fate of Cryptosporidium parvum and Cryptosporidium hominis oocysts and Giardia duodenalis cysts during secondary wastewater treatments. Parasitol. Res., 105: 689 - 696. DOI:10.1007/s00436-009-1440-y

Cutolo, S.A., Matté, M.H., Rocha, A.A. (2003): Monitoring of parasitological contamination in treated wastewater from activat- 
ed sludge system. Manag. Enviro. Qual., 17(1): 45 - 56. DOI: 10.1108/14777830610639431

Demar, M., Ajzenberg, D., Maubon, D., Djossou, F., Panchoe, D., Punwasi, W., Valery, N., Peneau, C., Daigre, J.L., Aznar, C., Cottrelle, B., Terzan, L., Dardé, M.L., Carme, B. (2007): Fatal Outbreak of Human Toxoplasmosis along the Maroni River: epidemiological, clinical, and parasitological aspects. Clin. Infect. Dis., 45 (7): e88-e95. DOI: 10.1086/521246

DUBINSKÝ, P., JURIŠ, P., MoncoL, D. (2000): Environmentalprotection against the spread of pathogenic agents of diseases through the wastes of animal production in the Slovak republic, Košice, Parasitological Institute, SAS, $170 \mathrm{pp}$.

Galván, A.L., Magnet, A., Izquierdo, F., Fenoy, S., Rueda, C., Vadillo, C.F., HenRiques-Gil, N., Del Aquila, C. (2013): Molecular Characterization of Human-Pathogenic Microsporidia and Cyclospora cayetanensis Isolated from Various Water Sources in Spain: a Year-Long Longitudinal Study. Appl. Environ. Microbiol., 79(2): 449 - 459. DOI:10.1128/AEM.02737-12

Guzmán, C., Jofre, J., Montemayor, M., Lucena, F. (2007): Occurrence and levels of indicators and selected pathogens in different sludges and biosolids. J.Appl. Microbiol.,103(6): 2420 - 2429. DOI: 10.1111/j.1365- 2672.2007.03487.x

JIMÉNEZ, B. (2007): Helminths (worms) eggs control in wastewater and sludge. In International Symposium on New Directions in Urban Water Management, UNESCO Paris, pp. 1 - 8

Jiménez, B., Mara, D., Carr, R., Brissaud, F. (2010): Wastewater treatment for pathogen removal and nutrient recovery. Suitable systems for use in developing countries. In Wastewater Irrigation and Health: Assessing and Mitigating Risks. Low-Income Countries, London, Dreschel and Scott Editors, Earthscan Press, pp. $149-170$

JuRIŠ, P., BRezA, M., Schmidtová, D., VenglovskÝ, J. (1991): Dissemination and survival of endoparasitic germs in the environment. Vet. Med. (Praha), 36(11): 665 - 671

Juriš, P., Papajová, I. (2012): Soil contaminted with parasitic germs as a source of parasitic zoonoses in the localities with low hygienic standard - Roma settlements. Clin. Soc. Work J., 13(2): 37 - 40 Khanum, H., Shanuida Khanam, S., Sultana, M., Uddin, M.H., Chandra DHAR, R., ISLAM, M.S. (2012): Protozoan parasites in a wastewater treatment plant of Bangladesh. Univ. J. Zool. Rajshahi Univ., 31: $5-8$
KhOuja, L.B., Cama, V., XIAO, L. (2010): Parasitic contamination in wastewater and sludge samples in Tunisia using three different detection techniques. Parasitol. Res., 107(1): 109 - 116. DOI: 10.1007/s00436-010-1844-8

Konate, Y., Maiga, A.H., Basset, D. (2010): Helmints eggs and Protozoa cysts in stabilization ponds sludge in the soudano-sahelian climate Burkina Faso. In International Congres Smallwat, April, 2011 Seville Spain

MahVI, A.H., KIA, E.B. (2006): Helminth eggs in raw and treated wastewater in the Islamic Republic of Iran. East. Mediterr. Health J.,12 (1/2): 137 - 143

Mara, D. Horan, N. (2003): The Handbook of Water and Wastewater microbiology, London, UK, Elsevier, Academic Press, 819 pp.

Government of the Slovak Republic: Government Regulation no. 269/2010 laying down the requirements to achieve good water status (In Slovak)

OKojokwu, O.J., INABo, H.I., YAKUBU, S.E. (2014): Parasitological Profile of Raw Wastewater and the Efficacy of Biosand Filter in Reduction of Parasite Ova and Cysts. J. Appl. Sci. Environ. Manage, 18 (1): $5-9$

Rimárová, K. (2010): The Health of the Roma People in Central Eastern Europe, Košice, Equilibria, 100 pp.

Seviour, R., Nielsen, P.H. (2010): Microbial Ecology of Activated Sludge, London, UK, IWA Publishing, 667 pp.

SlifKo, T.R., Smith, H. V., Rose, J.B. (2000): Emerging parasite zoonoses associated with water and food. Int. J. Parasitol.,30: 1379 - 1393. DOI: 10.1016/S0020-7519(00)00128-4

SchaECHTER, M. (2009): Encyclopedia of Microbiology. $3^{\text {th }}$ Edition, The Boulevard, Langford Lane, Kidlington, Oxford OX5 IGB, UK, Academic Press is an imprint of Elsevier, 4600 pp.

The European Parliament and The Council of the European Union: Regulation of the European Parliament and Council Regulation (EC) No. 1137/2008 concerning urban wastewater

Turovskiy, I.S., Mathal, P.K. (2006): Wastewater sludge processing, Hoboken, New Jersey, Published by John Wiley \& Sons, Inc., $341 \mathrm{pp}$.

WHO (2006): Guidelines for the safe use of wastewater, excreta and greywater: Volume II - Wastewater use in agriculture, France, $196 \mathrm{pp}$.

WHO (2008): The global burden of disease: 2004 update. Geneva: WHO, 146 pp. 